\title{
Aplikasi Tata Cara Ibadah Berbasis Android
}

\author{
Evert S. Tangkudung ${ }^{(1)}$, Meicsy E. I. Najoan ${ }^{(2)}$, Dringhuzen J. Mamahit ${ }^{(3)}$ \\ Jurusan Teknik Elektro, Program Studi Informatika, Fakultas Teknik, UNSRAT, Manado 95115, e-mail: \\ 120216132@student.unsrat.ac.id, meicsynajoan@unsrat.ac.id, \\ yekke_mamahit@yahoo.com
}

\begin{abstract}
Abstrak - Gereja Masehi Injili di Minahasa adalah salah satu organisasi gereja di minahasa yang disingkat dengan GMIM. Dalam peribadatan GMIM Sendiri mempunyai Tata cara ibadah (Liturgy) yang digunakan. Pengertian dari liturgi adalah istilah yang berasal dari bahasa Yunani, leitourgia, yang berarti kerja bersama. Android merupakan sebuah sistem operasi yang digunakan pada kebanyakan smartphone dewasa ini. Antarmuka pengguna pada Android didasarkan pada manipulasi langsung, menggunakan masukan sentuh yang serupa dengan tindakan di dunia nyata. Sampai sekarang, android memiliki berbagai macam versi yang memiliki berbagai fitur baru. Saat ini tata cara ibadah atau liturgy yang di pakai di GMIM masih dalam bentuk manual, sehingga mengakibatkan penyediaan jumlah kertas yang tidak sesuai dengan jumlah jemaat yang hadir. Selain itu dengan menggunakan media kertas ini sering terjadi pemborosan kertas dan banyak menghasilkan sampah di lingkungan gereja. Berdasarkan permasalahan ini peneliti tertarik untuk mengembangkan suatu penelitian dalam bentuk aplikasi android yang dapat membantu mempermudah jemaat mendapatkan informasi tentang tata cara ibadah serta informasi mengenai ibadah sepekan dalam bentuk aplikasi yang terpasang di Smartphone khususnya OS android. Bahasa pemograman yang digunakan adalah bahasa pemograman java yang mendukung aplikasi berbasis android. Data-data untuk aplikasi dibuat menggunakan database MySQL. Dari tahapan-tahapan dalam penelitian ini dihasilkan sebuah aplikasi tata cara ibadah berbasis android. Fitur-fitur yang terdapat dalam aplikasi ini yaitu,tata cara ibadah,jadwal ibadah,lirik lagu yang bertujuan memudahkan dalam penyajian informasi.
\end{abstract}

Kata Kunci : Aplikasi Tata Cara, Application Development, Android, GMIM, Rapid, Sistem Informasi.

Abstract - The Evangelical Christian Church in Minahasa is one of the church organizations in Minahasa which is abbreviated as GMIM. In its own GMIM Worship has the Ordinance of worship (Liturgy) used. The sense of the liturgy is a term derived from Greek, leitourgia, meaning joint work. Android is an operating system used on most smartphones today. The user interface on Android is based on direct manipulation, using touch feedback similar to the action in the real world. Until now, android has various versions that have various new features. Currently the ordinance of worship or liturgy in use in GMIM is still in manual form, resulting in the provision of paper quantities that are not in accordance with the number of congregations present. In addition, using paper media is often a waste of paper and a lot of waste in the church environment. Based on this problem researchers interested in developing a research in the form of android applications that can help facilitate the congregation to get information about the procedures of worship as well as information about worship a week in the form of applications installed in the Smartphone, especially android OS. The programming language used is a java programming language that supports android based applications. The data for the application is created using MySQL database. From the stages in this study produced an application of android-based worship procedures. The features contained in this application is, the ordinance of worship, the schedule of worship, the lyrics of the song that aims to facilitate the presentation of information.

Keywords: Application Procedures, Application Development, Android, GMIM, Rapid, Information Systems.

\section{PENDAHULUAN}

Gereja Masehi Injili di Minahasa adalah salah satu organisasi gereja di minahasa yang disingkat dengan GMIM. Gmim juga merupakan salah satu gereja terbesar di Indonesia yang beraliran Calvinisme. Gmim didirikan di Minahasa, sulawesi utara pada tahun 1934 setelah dipisahkan dari Gereja induknya, Indische Kerk. pada tanggal 30 September $1943 \mathrm{Gmim}$ dinyatakan sebagai Gereja mandiri. tanggal ini diperingati sebagai hari jadi Gmim [1].

Dalam peribadatan Gmim sendiri mempunyai Tata cara ibadah (Liturgy) yang digunakan. pengertian dari liturgi adalah istilah yang berasal dari bahasa Yunani, leitourgia, yang berarti kerja bersama. kerja bersama ini mengandung makna peribadatan kepada Allah dan pelaksanaan kasih, dan pada umumnya istilah liturgy lebih banyak digunakan dalam tradisi kristen. saat ini tata cara ibadah atau liturgy yang di pakai di Gmim masih dalam bentuk manual, sehingga mengakibatkan penyediaan jumlah kertas yang tidak sesuai dengan jumlah jemaat yang hadir. seperti kita ketahui bersama bahwa dalam suatu peribadatan jumlah jemaat yang hadir tidak dapat di prediksi dan dipastikan. Hal ini menjadi permasalahan untuk para petugas gereja dalam hal ini untuk penyediaan lembar tata cara ibadah. Selain itu dengan menggunakan media kertas ini sering terjadi pemborosan kertas dan banyak menghasilkan sampah di lingkungan Gereja. dengan adanya teknologi android peneliti akan membuat aplikasi Tata cara ibadah, jadi dengan begitu lebih memperhemat anggaran biaya karna tidak perlu lagi mencetak lembar tata cara ibadah 
perminggu.

Berdasarkan permasalahan ini peneliti tertarik untuk mengembangkan suatu penelitian dalam bentuk aplikasi android yang dapat membantu mempermudah jemaat mendapatkan informasi tentang tata cara ibadah serta informasi mengenai ibadah sepekan dalam bentuk aplikasi yang terpasang di Smartphone khususnya OS android.

\section{LANDASAN TEORI}

\section{A. Android}

Android adalah sistem operasi berbasis Linux yang dirancang untuk perangkat seluler layar sentuh seperti telepon pintar dan komputer tablet. Android, Inc. didirikan di Palo Alto, California, pada bulan Oktober 2003 oleh Andy Rubin (pendiri Danger), Rich Miner (pendiri Wildfire Communications, Inc.), Nick Sears (mantan VP T-Mobile), dan Chris White (kepala desain dan pengembangan antarmuka WebTV) untuk mengembangkan "perangkat seluler pintar yang lebih sadar akan lokasi dan preferensi penggunanya". Tujuan awal pengembangan Android adalah untuk mengembangkan sebuah sistem operasi canggih yang diperuntukkan bagi kamera digital, namun kemudian disadari bahwa pasar untuk perangkat tersebut tidak cukup besar, dan pengembangan Android lalu dialihkan bagi pasar telepon pintar untuk menyaingi Symbiandan Windows Mobile (iPhoneApple belum dirilis pada saat itu). Meskipun para pengembang Android adalah pakar-pakar teknologi yang berpengalaman, Android Inc. dioperasikan secara diam-diam, hanya diungkapkan bahwa para pengembang sedang menciptakan sebuah perangkat lunak yang diperuntukkan bagi telepon seluler [2].

\section{B. Android Studio}

Android Studio adalah sebuah lingkungan pengembangan terpadu IDE (Integrated development Environment) untuk mengembangkan pada platform android. Android Studio merupakan software yang dapat meningkatkan produktivitas dan mempermudah pekerjaan dalam membuat aplikasi android. Android Studio menyediakan berbagai fitur dan peralatan yang sangat dibutuhkan oleh para developer (pengembang) dengan pemograman java. Android Studio di perkenalkan oleh google secara resmi pada tahun 2013. Dalam penelitian ini penulis menggunakan Bahasa java sebagai Bahasa pemograman [3].

\section{C. $M y S Q L$}

Pengertian MySQL termasuk kedalam jenis softwere pada Rational Database management System (RDBMS) pada sebuah management Database sebagai basis data pada sebuah perusahaan misalnya, penggunaan informasi dilakukan untuk menyimpan banayak data yang jumlahnya tidak terbatas. Laludata tersebut dapat di olah untuk kepentingan tertentu secara sedemikian rupa untuk kebutuhan tersebut. MySQL telah sejak lama digunakan dalam pengelolaan data dengan menggunakan Bahasa SQL, sebagai proses pengoprasian basis data (database). Pada dasarnya MySQL adalah turunan salah satu konsep utama pada basis data yang sebelumnya sudah ada yaiutu SQL (Structured Query Language).

\section{Java}

Java adalah Bahasa pemograman yang mirip dengan $\mathrm{C} / \mathrm{C}+$. terutama adalah Bahasa pemrograman yang umum di gunakan untuk pemrograman web. Salah satu keunggulan dari java adalah dapat berjalan di banyak platform parangkat keras dan perangkat lunak sehingga pengembang aplikasi dan pemrograman dapat menuliskan program dengan menuliskannya dimana saja, di platform system operasi apapun serta dikembangkannya computer yang ada saat ini. Java juga adalah Bahasa pemrograman yang cukup ampuh untuk digunakan menyusun aplikasi yang canggih karena dalam perancangan dan pengimplikasiannya. Java merupakan Bahasa pemrograman berorientasi objek pendorong penggunaan kode modular yang mudah di rawat di banding Bahasa pemrograman berorientasi objek yang lain. Selain itu juga java memiliki berbagai fasilitas yang bagus dan canggih, seperti ekstensibilitas, keamanan, serta multithreading (pengeksekusian beberapa program sekaligus) [4].

\section{E. Smartphone}

Menurut williams \& sawyer (2011), Smartphone adalah telepon selular dengan mikroprosesor, memori, layar dan modem bawaan. Smartphone merupakan ponsel multimedia yang menghubungkan fungsional PC handset sehingga menghasilkan gadget yang mewah. Dimana terdapat pesan teks,kamera pemutar musik, video, game, akses email, tv digital, search engine,pengelola informasi pribadi, fitur GPS, jasa telepon internet dan bahkan terdapat telepon yang juga berfungsi sebagai kartu kredit [5].

\section{F. Rapid Application Development (RAD)}

RAD merupakan model proses perangkat lunak yang menekankan pada daur pengembangan yang singkat. RAD merupakan versi adaptasi cepat dari model waterfall, dengan menggunakan pendekatan konstruksi komponen (Pressman, 2005). Dari penjelasan Pressman ini, satu perhatian khusus mengenai metodologi RAD dapat diketahui, yakni implementasi metode RAD akan berjalan maksimal jika pengembang aplikasi telah merumuskan kebutuhan dan ruang lingkup pengembangan aplikasi dengan baik.

\section{G. JSON}

JSON (JavaScript Object Notation) adalah format pertukaran data yang ringan, mudah dibaca dan ditulis oleh manusia, serta mudah diterjemahkan dan dibuat (generate) oleh komputer. Format ini dibuat berdasarkan bagian dari 
Bahasa Pemprograman JavaScript, Standar ECMA-262 Edisi ke-3 - Desember 1999. JSON merupakan format teks yang tidak bergantung pada bahasa pemprograman apapun karena menggunakan gaya bahasa yang umum digunakan oleh programmer keluarga $\mathrm{C}$ termasuk $\mathrm{C}, \mathrm{C}++, \mathrm{C \#}$, Java, JavaScript, Perl, Python dll. Oleh karena sifat-sifat tersebut, menjadikan JSON ideal sebagai bahasa pertukaran-data (json.org). Nilai pada JSON dapat berupa String, Number, Object, Array, Boolean (true or false) dan null.

\section{H. Unified Modelling Language (UML)}

UML (Unifed Modeling Language) adalah salah satu standar bahasa yang banyak digunakan di dunia industri untuk mendefinisikan requirement, membuat analisis \& desain, serta menggambarkan arsitektur dalam pemrograman berorientasi objek (Rosa dan Shalahuddin, 2015).

\section{Gereja Masehi Injili di Minahasa (GMIM)}

GMIM merupakan salah satu gereja terbesar di Indonesia yang beraliran Calvinisme. Jadi jelas GMIM merupakan gereja yang beraliran Protestan. Sejak pemisahan (yang disebut "Schisma besar") antara gereja Barat (Katolik) dan Timur (Ortodok) tahun 1045 dalam perjalanan sejarah, sekelompok orang yang tidak setuju dengan doktrin yang dianut Katolik, memisahkan diri menjadi Protestan (tahun 1517). Sejak itu ada 2 aliran gereja besar yang mulai berexpansi ke seluruh dunia termasuk Indonesia.

\section{METODOLOGI PENELITIAN}

\section{A. Objek dan Lokasi Penelitian}

Penelitian ini mengambil studi kasus yang bertempat di lingkungan gedung gereja GMIM Sion Matungkas. Objek yang berkaitan dalam penelitian ini mengambil buku tata cara ibadah GMIM.

\section{B. Metode Pengumpulan Data}

Metode pengumpulan data dalam penelitian ini terbagi atas :

\section{Observasi}

Pada bagian ini penulis melakukan observasi pada objek penelitian dengan tujuan untuk memperoleh berbagai data konkret secara langsung di lapangan atau tempat penelitian.

2. Kuesioner

Pengumpulan data dengan cara memberikan beberapa pertanyaan kepada responden mengenai aplikasi yang akan dibuat. Penulis menyebarkan kuesioner Ke 30 responden yang terdiri dari beberapa jemaat, Ketua jemaat dan sekertaris jemaat.

C. Analisis Kebutuhan
Pada bagian ini, penulis menganalisis kebutuhan dalam merancang dan membangun aplikasi. Kebutuhan tersebut adalah berupa bahan dan alat untuk melakukan penulisan kode sumber dan pembangunan database. Bahan dan alat yang digunakan adalah:

1) Laptop

2) Android Studio 2.3.1

3) XAMPP

4) Star UML

\section{5) Google Chrome}

D. Perancangan Aplikasi

Untuk aplikasi antarmuka dibangun menggunakan Android Studio, dengan bahasa pemrograman Java. Program dirancang akan menggunakan 4 (empat) buah form, yaitu :

1) Form Utama, form ini menampilkan halaman utama sebelum pilihan form navigasi.

2) Form Jadwal Ibadah, form ini berfungsi untuk menampilkan jadwal ibadah.

3) Form Informasi, form ini akan menampilkan informasi mengenai ibadah yang akan datang dan sebagainya.

4) Form Lirik Lagu, form ini berfungsi untuk mencari dan menampilkan lirik lagu yang dicari oleh user.

\section{E. Perancangan Sistem}

Sistem ini memiliki 3 fungsi utama, yaitu fitur untuk menampilkan informasi, fitur untuk menampilkan jadwal ibadah, dan fitur untuk mencari dan menampilkan lirik lagu.

Gambar 1 menjelaskan bagaimana alur kerja dari aplikasi yang akan dirancang. Pertama, user masuk pada tampilan utama. Kemudian user memilih 1 dari 3 menu yang diberikan, yaitu tata cara ibadah jadwal ibadah, dan lirik lagu.

Pada bagian tata cara ibadah, user akan dinavigasi ke halaman tersebut, di mana sistem akan menampilkan tata cara ibadah yang sedang berlangsung. Pada bagian jadwal ibadah, user akan ditampilkan sebuah interface mengenai jadwal ibadah yang akan berjalan minggu depan ataupun pada periode yang sedang berjalan. Pada bagian lirik lagu, user diminta untuk memasukkan judul dari lagu yang akan dilihat liriknya. Sistem akan mencari lagu yang dimaksud dan menampilkan lirik lagu sesuai dengan judul yang dicari oleh user. 


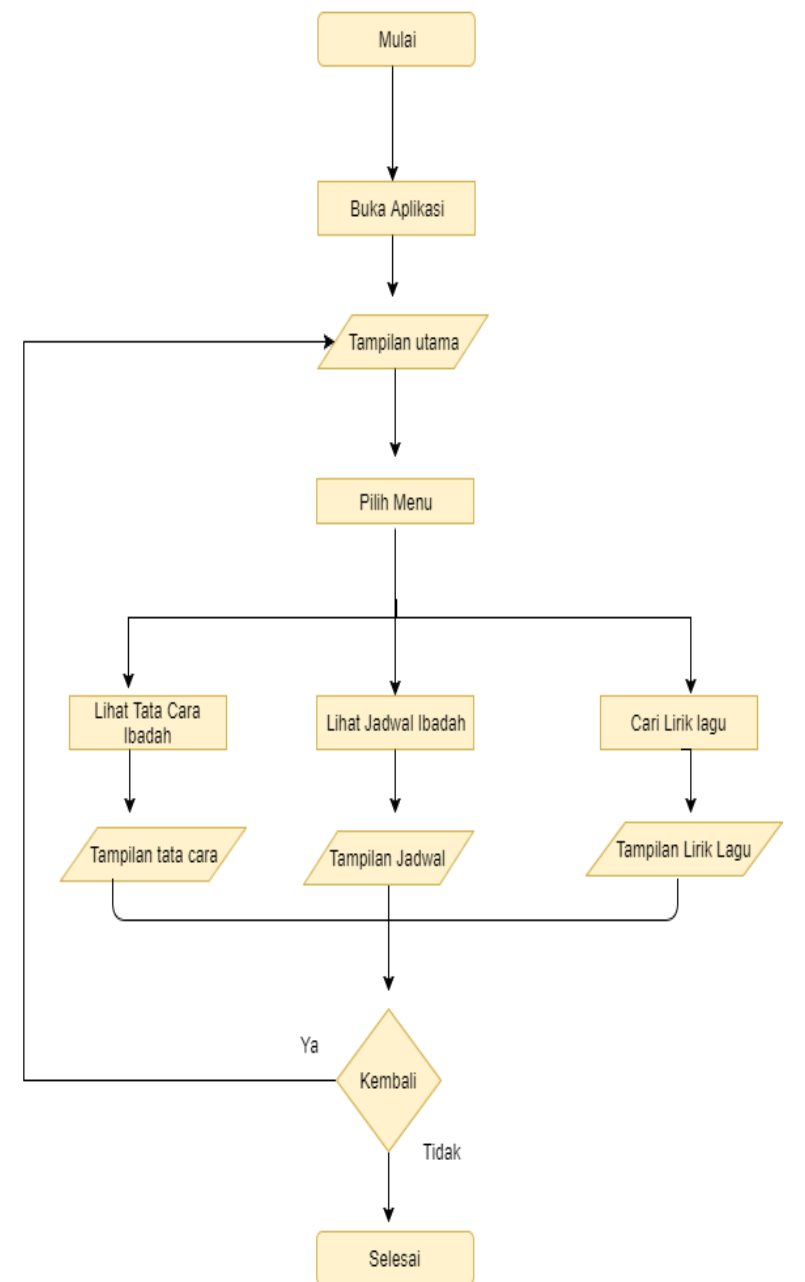

Gambar 1. Diagram Alir Aplikasi Tata Cara Ibadah GMIM.

F. Perancangan Database

Pada bagian ini, penulis merancang database yang akan digunakan untuk membangun aplikasi yang telah dibangun sebelumnya. Ada 4 tabel database yang akan dirancang pada aplikasi, yaitu "informasi", "jadwal_ibadah", "lirik_lagu", dan "tata_cara_ibadah".

1) Tabel 1 menjelaskan tentang databasse informassi kegiatan gereja.

\begin{tabular}{ccc} 
& \multicolumn{2}{c}{ Tabel 1 Daftar Informsi } \\
\hline Nama Kolom & $\begin{array}{c}\text { Tipe } \\
\text { Data }\end{array}$ & Atribut \\
\hline Id & Int & Primary key \\
\hline Tgl & Varchar & \\
\hline Tempat & Varchar & \\
\hline Informasi & Varchar & \\
\hline Jenis_Kegiatan & Varchar & \\
\hline
\end{tabular}

2) Tabel 2 merupakan database dari jadwal ibadah. Tabel 2 Jadwal Ibadah

\begin{tabular}{ccc}
\hline $\begin{array}{c}\text { Nama } \\
\text { Kolom }\end{array}$ & Tipe Data & Atribut \\
\hline Id & int & Primary key \\
\hline Jenis_ibadah & Varchar & \\
\hline Tempat & Varchar & \\
\hline Waktu & Varchar & \\
\hline Tgl & Varchar & \\
\hline Khadim & Varchar & \\
\hline
\end{tabular}

3) Table 3 merupakan database dari llirik lagu.

\begin{tabular}{ccc} 
& \multicolumn{2}{c}{ Tabel 3 Lirik Lagu } \\
\hline $\begin{array}{c}\text { Nama } \\
\text { Kolom }\end{array}$ & Tipe Data & Atribut \\
\hline Judul & Varchar & $\begin{array}{c}\text { Primary } \\
\text { Key }\end{array}$ \\
\hline Jenis & Varchar & \\
\hline Nomor & Varchar & \\
\hline Lirik & Varchar & \\
\hline
\end{tabular}

4) Table 4 merupakan tampilan dari database tata cara ibadah.

Tabel 4 Tata Cara Ibadah

\begin{tabular}{ccc}
\hline Nama Kolom & Tipe Data & Atribut \\
\hline Id & Int & \\
\hline Jenis_ibadah & Varchar & \\
\hline Tata_cara & Varchar & \\
\hline
\end{tabular}

\section{HASIL DAN PEMBAHASAN}

A. Pembuatan Aplikasi

Tahapan Pembuatan Aplikasi Tahap pembuatan aplikasi ini adalah tahap implementasi aplikasi berdasarkan rancangan aplikasi pada bab sebelumnya. Hal yang pertama dilakukan dalam membuat aplikasi adalah proses pengkodingan aplikasi. Pembuatan koding aplikasi dibuat dengan menggunakan Android Studio.

Setelah melakukan tahap pengkodingan, tahap selanjutnya dalam implementasi aplikasi adalah membuat database untuk melakukan proses penyimpanan data pada aplikasi. Penyimpanan data tidak menggunakan localhost, melainkan dengan menggunakan jaringan internet. Untuk itu penulis membuat database pada web hosting.

\section{B. Ujicoba Aplikasi}

Setelah aplikasi dibangun, langkah berikutnya adalah membangun dan menguji aplikasi antarmuka untuk output di komputer dan pengolahan database. Dalam tahap ini dilakukan GUI pada aplikasi yang dirancang sebelumnya. 
1)

\section{Splash Screen}

Tampilan ini dapat dilihat pada gambar 2 .

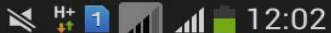

\section{App Tata Cara}

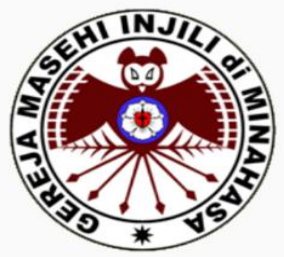

Gambar 2. Tampilan Splash Screen

\section{2) Tampilan Awal Aplikasi}

Gambar 3 adalah tampilan untuk halaman awal dari aplikasi tata cara ibadah dengan menampilkan informasi tentang kegiatan gereja setiap pekan khususnya informasi lomba-lomba yang ada di Gereja.

\begin{tabular}{l}
\hline App Tata Cara \\
\hline Volley Ball \\
Lomba antar Kolom \\
17 September 2017 Gmim Sion Matungkas \\
Koor Pemuda \\
Lomba koor antar wilayah \\
19 Oktober 2017 Gmim Sentrum Tatelu \\
Panjat pinang \\
Antar kolom \\
25 Maret 2017 Gmim Sion Matungkas
\end{tabular}

Gambar 3. Tampilan Awal Aplikasi.

3) Tampilan Navigasi Aplikasi

Gambar 4 adalah tampilan navigasi aplikasi diantaranya terdapat beberapa fitur atau menu yang nantinya akan dipilih oleh user sesuai yang diinginkan.

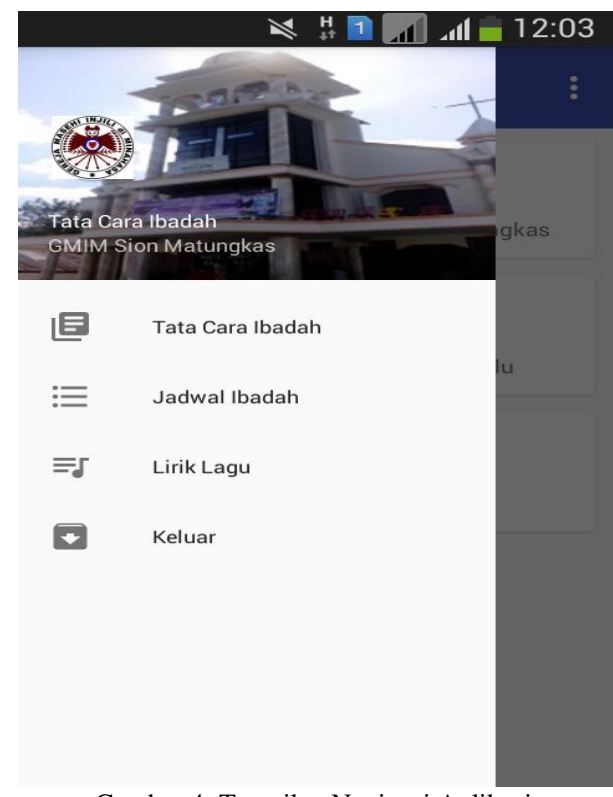

Gambar 4. Tampilan Navigasi Aplikasi.

\section{4) Tampilan Tata Cara Ibadah}

Jika user mengklik menu tata cara ibadah maka akan muncul list tata cara ibadah yang akan digunakan dalam peribadatan setiap pekan kelebihan dari aplikasi ini bukan hanya menawarkan tata cara ibadah hari minggu namun semua tata cara yang pakai dalam peribadatan Gmim sudah tersedia dari tata ibadah minggu, kolom, pengucapan syukur, paska, pranatal, duka.

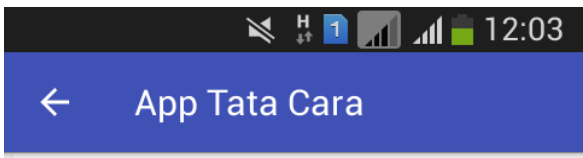

Ibadah Minggu

TATA IBADAH MINGGU BENTUK IV Minggu, 23 April 2017

PERSIAPAN

Koord. Penyelenggara Ibadah : (diawali ucapan selamat datang) Marilah kita berdiri,

kita mulaikan ibadah ini dengan menyanyi

KJ NO.3 "Kami puji Dengan Riang"

Kami puji dengan riang Dikau Allah yang besar,bagaikan bunga trima siang,Hati kami pun mekar.Kabut dosa dan derita kebimbangan t'lah leyap.Sumber suka dan abadi b'ri sinarMu menyerap.

Gambar 5. Tampilan Tata Cara Ibadah. 
Tampilan Jadwal Ibadah

Jika user mengklik menu jadwal ibadah maka akan muncul lits jadwal ibadah sepekan dari jadwal ibadah Kolom,Pkb,Wki, Pemuda,Remaja, dan ASM.

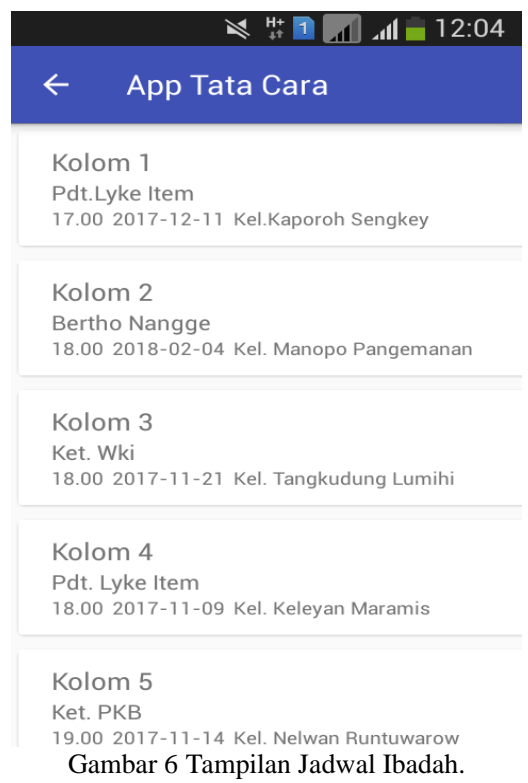

\section{6) Tampilan Lirik Lagu}

Gambar 7 adalah menu pencarian lirik lagu, ketika user ingin mencari lirik lagu yang diinginkan harus memasukan judul lirik lagu terlebih dahulu maka aplikasi akan mempilkan lirik lagu sesuai judul yang di masukan pada menu pencarian.

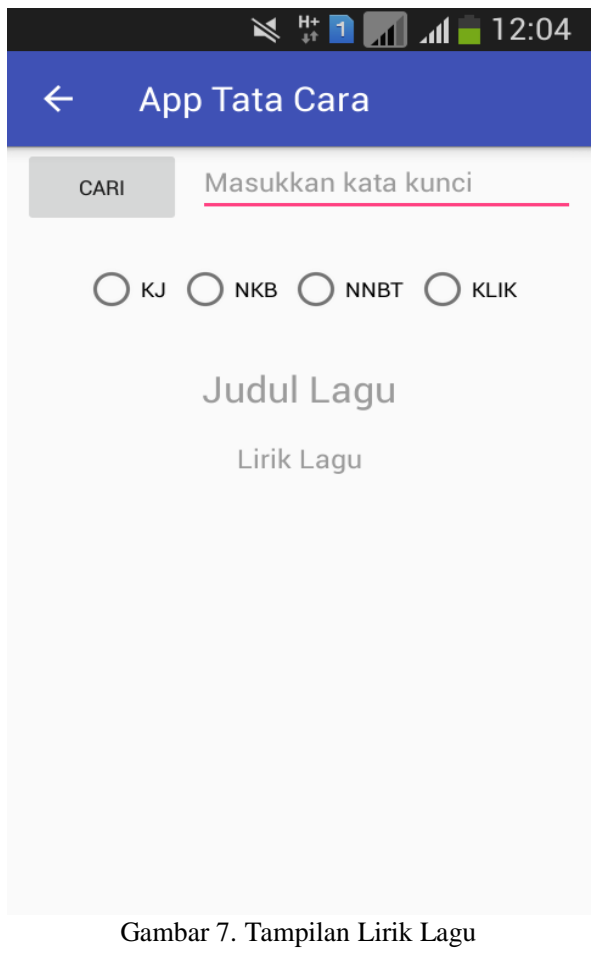

\section{PENUTUP}

A. Kesimpulan

Dalam menyelesaikan masalah yang ada khususnya mendapatkan informasi tentang tata cara ibadah gmim , penulis sudah dapat menerapkan konsep rekayasa perangkat lunak serta analisa dan perancangan sistem yang dapat dikatakan lumayan baik untuk membantu user mendapatkan informasi.

Aplikasi tata cara ibadah ini dikembangkan dengan menggunakan metode RAD (Rapid Application Development) metode ini dipilih karena proses pembuatan aplikasi dapat dilakukan dengan cepat dimana aplikasi dapat di terbitkan perversi-versinya, dengan metode ini proses analisah dan perancangan aplikasi dapat lebih terstruktur sehingga menghasilkan sebuah rancangan dengan dokumentasi yang lengkap.

Hasil dari penelitian ini berupa sebuah Aplikasi Tata cara ibadah berbasis android yang sudah siap digunakan. yang diharapkan dengan adanya aplikasi ini dapat membantu para user mendapatkan informasi tentang tata cara ibadah dan juga informasi lainnya mengenai kegiatan ibadah dalam Gereja.

B. Saran

Berdasarkan hasil penelitian dan kesimpulan mengenai Aplikasi tata cara Ibadah ini maka diajukan saran sebagai berikut :

1. Aplikasi ini dapat dikembangkan lebih informatif dan menarik dalam segi tampilan bagi yang akan mengembangkannya.

2. Menambahkan fitur-fitur tambahan lagi yang berguna untuk membantu user agar dapat lebih mudah mendapatkan informasi tentang ibadah dalam Gereja.

3. Aplikasi ini masih bisa dikembangkan lagi terutama pada fitur lirik lagu dapat ditambahkan fungsi untuk pencarian lirik lagu yang digunakan dalam peribadatan Gmim.

\section{DAFTAR PUSTAKA}

[1] Bidang Ajaran, Pembinaan, dan Pengembalaan Sinode Gmim, Tomohon 2013

[2] Huda, Arif Akbarul. (2013). 9 Aplikasi Android Buatan Sendiri .Yogyakarta : Penerbit ANDI.

[3] Hendricky Johanes Talukaki, Aplikasi Sistem Informasi Objek Dan Event Pariwisata Kota Manado Berbasis Android 2015

[4] Y.supardi, "Mengenal java dan Android," Semua bisa menjadi programmer Android, Jakarta: PT Elex Media Komputindo ,2011.

[5] Yayuk Devi TriantyOnee Marleen 2014 dari penelitian yang bejudul Aplikasi Android untuk pencarian lokasi tempat ibadah di wilayah bekasi 8 Oktober 2014 


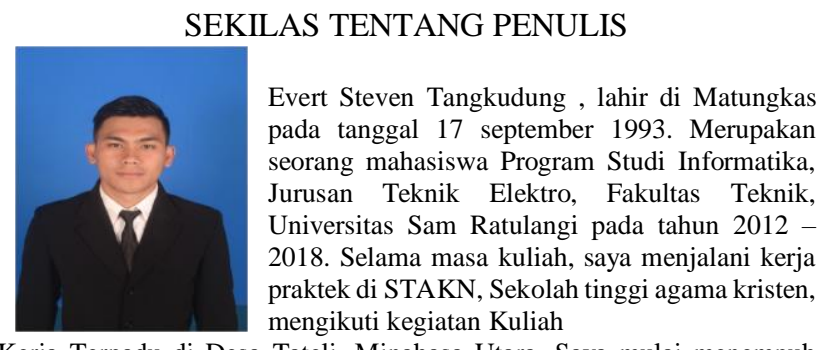

Kerja Terpadu di Desa Tateli, Minahasa Utara. Saya mulai menempuh pendidikan di SD 1 Matungkas (2000-2006). Kemudian melanjutkan ke SMP 1 Tatelu (2006-2009). Setelah itu saya menempuh pendidikan di SMK Negeri 3 Manado (2009-2012). Setelah lulus, di tahun 2012 saya melanjutkan pendidikan di Universitas Sam Ratulangi Manado, mengambil Program Studi S-1 Teknik Informatika di Jurusan Elektro Fakultas Teknik. 